\title{
The Role Of Traditional Leaders In The Promotion Of Cultural Tourism In The South Coast Of Kwazulu- Natal: A Case Study Of Umzumbe Municipality
}

\author{
Dr Erasmus Mnguni \\ Department of Hospitality and Tourism, Durban University of Technology, South Africa \\ Erasmus@dut.ac.za
}

\section{Doi:10.5901/jesr.2014.v4n6p265}

\section{Abstract}

\begin{abstract}
Tourism was identified by the government post 1994 democratic election as one of the mechanisms that could be used to fight poverty. Traditional leaders were also incorporated into the government structures so that they could also play a meaningful role in the development of the country of their birth. This paper seeks to look at the role played by the traditional leaders in the promotion of cultural tourism in the areas under their chieftaincy post the 1994 democratic elections. Through purposive and theoretical data gathering sampling methods, unstructured interviews were conducted to 18 traditional leaders, 1 Umzumbe municipality local economic development officer and 1local tour guiding service provider. The study used methodological triangulation in the analysis of the results and found that there were mixed feelings amongst the traditional leaders regarding their role with some feeling that they are being side-lined by the local government when it comes to development issues as they are not invited to meetings where such issues are discussed. Others of course felt that they are already instrumental in the promotion of cultural tourism in their areas of jurisdiction citing cultural projects that are in the pipeline as evidence. The study concludes that due to lack of synergy between the municipality officials and the traditional leaders there is still a lot of untapped wealth in rural south coast, which through tourism awareness campaigns, partnership between local government, private sector and local traditional leadership can be used to turn things around.
\end{abstract}

Keywords: leadership, tourism, development, culture

\section{Introduction}

Recently there has been growing interest globally in tourism as an instrument that could be used to boost economic growth particularly in less developed countries. The possibility of the creation of jobs through tourism which featured prominently in debates on tourism worldwide has generated wide interest in the study of tourism and much recent research on tourism points to the fact that cultural tourism can present many opportunities which can benefit the poor.

Due to South Africa's natural beauty, rich culture, arts, prominent heritage sites, language and so on tourism has also found a space in the government's programmes right from the national government to local governments. Taking advantage of the fact that I live in the South Coast of Kwa Zulu- Natal, I took an interest in the development issues of the Umzumbe municipality. This interest prompted me to conduct a situational analysis of the area. Through the situational analysis exercise I discovered that Umzumbe municipality comprises largely of communal land with 17 traditional authority areas. Noticeable was the fact that areas falling under the tribal authorities were poor compared to a small percentage along the coastline which is semi- urban, yet these areas were rich in culture which could easily be transformed into cultural tourism. I then took liberty to look at the Umzumbe Integrated Development Plan document of 2012/2013-2016/2017. To my delight, I learned that tourism was very much part of the Umzumbe Municipality Integrated development plan. In fact, the study conducted by the Umzumbe municipality pointed to the fact that there was a great potential in tribal authorities for cultural tourism (Umzumbe municipality integrated development plan, 2012/20132016/2017).

In support of the concept of tourism development, even the World Tourism Organisation is of the opinion that tourism could be used positively to create jobs thus bringing in the much needed economic freedom (World Tourism Organisation 2004) In fact, the World Tourism Organisation, in its 2020 vision, puts cultural tourism as number one on the priority lists because, in its view "cultural tourism stands out as it outperforms other tourist segments in terms of growth". This view is also shared by many authors who have written authoritatively and extensively on the study of tourism ( Ivanovic, 2008, Anand,2007, Timothy, 2011, Wanda, 2009 etc.) On the same vein, in his key note address in a cultural tourism conference held in Port Elizabeth, a Calabash tours representative also pointed out that the South 
African Tourism data placed cultural tourism high on the list of favoured tourist attractions in the country with figures such as $85 \%$ of Americans, $60 \%$ Asians and $64 \%$ of the domestic market. He, however, still felt that there was still room for growth in this area (Calabash tours) http:www.calabashtours.co.za/ethics/resources/70.html accessed on 2013/06/24

These facts provoked deep thoughts in me and I concluded that I needed to take a participative role in ensuring that cultural tourism is used as an economic tool particularly in rural areas because rural communities, in my view, are still marginalised. Development is very slow in rural areas. This view is even supported by Smith (2009) when she says "many of the world's most economically and socially marginalised groups live in such areas, and it is necessary to consider how far tourism may be considered to be a positive development option". In addressing the situation I felt that traditional leaders, by virtue of their positions, are closer to the people and are therefore in a better position to play a major role in the promotion of cultural tourism in the areas of their jurisdiction. This notion is also shared by Kegakilwe (SA NEWS.gov.za, 2010 South African Government News Agency, and Republic of South Africa) http://www.sanews.gov.za/south-africa/traditional--vital-rural-development accessed on 2013/06/24. In a two-day summit on the role of traditional leaders, he emphasised the developmental role traditional leaders are to play in rural development. Among other things, he exhorted them to remember the Ubuntu philosophy which says you are what you are because of others. In putting this across his exact words were "you are leaders because of the people and you are the centre of driving development in your communities". Whilst I am aware that the problem is widespread, the South Coast of KwaZulu - Natal attracted my interest, perhaps as a start. Attempts to cover the whole province would have proved to be an overambitious exercise and surely would have led to the failure of the project due to time constraints and the size of the province.

However, be that as it may, the big question was: given the economic situation in the South Coast, particularly in tribal authorities, what role are the traditional leaders playing in the promotion of cultural tourism for the benefit of their subjects and a country as a whole?

As evidenced above, issues regarding the role of traditional leadership in the new dispensation have been debated but it is still not very clear as to what their role is. In fact to my surprise and horror, when I was interviewing the local chief of the Mathulini tribal authority, he made it abundantly clear that tribal authorities in the Kwa Zulu- Natal province were still using the guidelines of the old homeland system in the management of the tribal land under their jurisdiction.

In this paper I will investigate the role of traditional leadership in the new dispensation with a focus on the promotion of cultural tourism. I will also look at the challenges they may face in fulfilling their role and then determine how these can be turned into opportunities. In presenting this argument I will first discuss different perspectives on and the rationale for traditional leadership involvement in the promotion of cultural tourism.

This will be followed by a discussion on the role of traditional leadership in the promotion of cultural tourism. One part of the discussion will include the general functions of a traditional leader and the role in governance, indicating that their voices are important components of the community. The last section will look at the challenges and opportunities

\section{Traditional Leadership}

Historically the role of traditional leadership was to allocate land and intervene in family feuds. This sufficed at the time because the community lived a simple life- their survival was based on subsistence farming and livestock. However, through evolution of community lifestyle, there is a great need for a shift of mind set. Wealth in the form of monetary value has taken a centre stage and central to this is economic development.

According to Hlengwa (in Keulder, 1998: 3) traditional leadership was known among other things, for the following:

- Act as a symbol of unity

- Maintain peace

- Preserve customs and culture

- Allocate land to subjects

- Resolve disputes and faction fights

- Conduct mediation

- Promote the identity of communities and promulgate tribal regulations

Whilst this was useful at the time, the change of community lifestyle from that of being traditionalists to Western lifestyle dictates that the focus of traditional leadership move away from the old practices to economic development of their areas for the benefit of their subjects.

In support of this assertion, a seminar on heritage and cultural tourism as a means of economic development for rural areas presented by the National House of traditional leaders in July 20, 2013 clearly delineated the role of traditional 
leaders on matters of economic development. To contextualise these roles, I want to focus on specific roles in development and tourism. In this presentation it was made clear that in sections 19 and 20 of the Traditional Leadership and Governance Framework Act, the following roles are allocated to traditional leaders:

- Economic development

- Tourism

- Management of natural resources

- $\quad$ Arts and culture

- Environment

This seminar further revealed that there was a huge outcry that traditional leaders are not taking advantage of their position in the community by aggressively pushing the cultural tourism agenda for the economic benefit of their subjects. Relevant to this issue and before we discuss cultural tourism promotion extensively, I feel that there is a need to first understand what we mean by cultural tourism. This definition is central to understanding of the rationale for the study, hence the subheading below

\section{The Concept of Cultural Tourism}

Cultural tourism (culture tourism) is the subset of tourism concerned with a country or region's culture, specifically the lifestyle of the people in those geographical areas, the history of those people, their art, architecture, religion(s) and other elements that helped shape their way of life. Cultural tourism includes tourism in urban areas, particularly historic or large cities and their cultural facilities such as museums and theatres. It can also include tourism in rural areas showcasing the traditions of indigenous cultural communities (i.e. festivals, rituals) and their values and lifestyles (Ivanovic, 2008)

Consistent with this study, however, much recent research on tourism points to the fact that the growth of international tourism has impacted positively on the demand for cultural tourism. In approaching this subject Smith (2009: 207) makes three points in favour of cultural tourism as a way of economic development. She avers "Cultural tourism often appears to be economically desirable prospects for the majority of governments since it implies in a country's people, its heritage and traditions as well as the natural and built environment." Similar to the observation made by Smith, the World Tourism organisation (2004) also includes lifestyles, festivals, folklore and handicraft in its definition of cultural tourism. Since the paper is not on cultural tourism per se, this short discussion on the definition of cultural tourism is enough to make us understand what the traditional leaders should be promoting in their areas of jurisdiction. In considering the promotion of cultural tourism as per the research topic, we also need to understand the Umzumbe municipality area where the study is taking place. This will help us contextualise the discussions

\section{The Umzumbe Municipality Demographics}

The South Coast of Kwa Zulu -Natal, in particular, is a fast developing part of the province, particularly the coastline. In terms of tourism the coastline boasts Hotels, B\&BS, lodges, beautiful beaches and so on. However, as you leave the coastline and move inland the picture changes from semi urban to deep rural. The hinterland is a stretch of about $60 \mathrm{~km}$ with 17 traditional authorities

Demographic information
\begin{tabular}{|l|c|}
\hline The extent of district & $5866 \mathrm{~km}$ \\
\hline Population & 704028 \\
\hline Number of households & 150600 \\
\hline Urban population & $16 \%$ \\
\hline Rural population & $84 \%$ \\
\hline Female population & $54 \%$ \\
\hline Male population & $46 \%$ \\
\hline Number of traditional authorities & 38 \\
\hline Extent of traditional authority land & $3450 \mathrm{~km}$ \\
\hline Extent of private and state land & $2415 \mathrm{~km}$ \\
\hline
\end{tabular}

Contained in this integrated development plan is the fact that clean water, electricity, sanitation, shelter and primary health care facilities are considered to be one of the key basic services they must provide.(Ugu municipality integrated development plan 2005/2006) 


\section{Materials and Methods}

I have learned over the years through my rural research experience that an unstructured question: Tell me about... elicits more information as it taps into the folklore story- telling skills the indigenous people of KwaZulu- Natal are highly known for. In addition, this approach is in line with the respect principles the Zulu nation is known for. Traditionally, a young person is not supposed to question adults. Rather, he must listen to what an adult is saying and accept that as facts. So, with the approach of tell me about... research participants' feel that they are in charge- they are not being questioned. Since the responses are normally broad and sometimes told in staccato phrases, I then follow up with probing questions for clarity and focus. The study itself is of a qualitative nature. Since there are 17 tribal authorities in the area, I used purposive and theoretical sampling to get my data. I did this because according to Rubin and Babbie (de Vos, Strydom, Fouche and Delport 2011) purposive sampling allows the researcher to use his judgement by choosing elements that possess attributes of the population suitable for the study. And theoretical sampling on the other hand will help to bridge gaps in the study thus helping us to refine ideas and make them meaningful. I have found that these two sampling methods complement each other.

Starting in one tribal authority and moving to the next, I managed to interview 10 traditional leaders. This was due to the impracticability of seeing all of them given their ever busy schedules

\section{Results and Discussions}

Interviews with some of the traditional leaders pointed to the fact that they feel that they are being marginalised by the Municipality when it comes to development issues. They are not invited to meetings. They also lamented that their role as traditional leaders has not been clearly defined in the new dispensation. Given the situation, they have resorted to using the old KwaZulu-Natal government's guidelines. They still see themselves as powerful people who must be respected at all costs and theirs is to only intervene in family feuds and the allocation of a piece of land to their subjects. The development issue, in their view, is the government responsibility. This is made worst by the fact that before any elections, government officials and other political organisations are seen driving around and making huge promises should they be elected into power. The political affiliation also plays a major role. If a certain traditional leader belongs to a certain political organisation, which is competing with a ruling party, for example, he tries his best to frustrate the area known to be a stronghold of a ruling party, hoping that such a move will force the electorates to join his party. Community members themselves still see development as the installation of electricity, road construction, provision of clean water and the allocation of low cost houses. And to make matters worse, the word "municipality" brings to the community fears of urbanisation which they resent so badly because they feel that urban life is expensive. The fear is that too much western influence will result in their areas being turned into townships. Traditional leaders on the other hand, fear that urbanisation will lead to their loss of power as the municipality takes full control. Some of these issues can be attributed to the lack of education. In my interviews with the traditional leaders, it was clear that there is little effort on the part of the government to capacitate them so that they can begin to understand their roles in a broader sense. Another contributing factor to this lack of interest in developmental issues is that through my observation, I have learned over the years that black communities are united only in social issues but very much divided in economic issues. This came out strongly in the interviews with the some of the tourism service providers and is unfortunate as it defeats the object of the formation of cooperatives. Mr Njilo, a Mathulini tribal authority tourism service provider was not in favour of cooperatives at all. He preferred to go it alone. This leads to secrecy- "once I find something useful, I am not going to tell others" kind of mentality

However it would be wrong to paint everyone with the same brush. A lengthy discussion with the chief of Emathulini tribal authority provided a spark and hope as he animatedly related to me how he and his tourism coordinator are planning to boost tourism in his area. He, among other things, cited a number of tourism projects in his area which are in the pipeline

\section{Municipality Views}

Clearly the local government of Umzumbe municipality is playing its role in the promotion of tourism, more especially cultural tourism which is aimed at addressing the issue of poverty in rural areas. The Umzumbe Municipality's integrated development programme (IDP, 2012/2013-2016/2017) is testimony to this assertion. Even more serious indication and determination to promote tourism is evidenced by the establishment of the Ugu South coast Tourism Company whose 
aims and objectives are to develop new tourism initiatives in the hinterland, improve existing tourist attractions and market the region as a premier tourist destination(South Coast tourism, 2010-2012) http:www.southcoasttourism.co.za/ en/aboutsouthcoast.aspx......accessed on 2013/06/24

In my interview with the Umzumbe municipality community development officer, it became clear that, although there are some hurdles here and there, the determination by the municipality to work together with the traditional leaders in ensuring the promotion of cultural tourism in the area is alive. Perhaps some of the resistance could be attributed to lack of awareness of tourism benefits amongst the community.

\section{My Position}

Some of the issues that came out during my interviews present stiff challenges; however, I am optimistic that they can be turned into opportunities. I say this because rural areas such as the South Coast, in particular, have a lot of untapped wealth- Umzumbe Municipality boasts of heritage sites, the first one being the commemoration of Ntelezi, a hero who participated in the Bhambata rebellion, cultural festivals are held annually by traditional leaders, virginity testing is still practiced and so on. When all these are performed, traditional gear is worn, Zulu dancing is performed, and beasts are slaughtered from which traditional cuisine is prepared. All these and many more things not mentioned here present cultural tourism business opportunities- one just needs to think out of the box, as it were, to take advantage of these opportunities

The black community needs to rid itself of the shackles of colonialism as some of them still seem to be conditioned to the lifestyle of the old order. The way things are going at the moment with education having taken a centre stage amongst the black youth, there is a glimmer of hope, however, that things will change for the better

\section{Conclusions and Recommendations}

It is clear that there is a lot of wealth in the rural communities but the traditional leaders are not taking advantage of it because they feel they are being side-lined by the local government. Whilst this may be so, they also need to take initiatives and maybe invite the municipality officials in their meeting. Hopefully the municipality will realise its mistake and learn that the traditional leaders are as enthusiastic about development issues as it is. This may lead to better working relationship which could benefit the community at large. Currently some traditional leaders and rural communities feel that tradition must be preserved rather than being turned into businesses. Tourism is seen as a foreign concept forgetting that even in the times of yore people used to travel even though a traveller at the time was not charged for the hospitality and accommodation given to him.

In her speech Nkandu Luo minister of Chiefs and Traditional Affairs in Zambia recommended that rituals should also be turned into tourist attractions. Whilst I am not pessimistic about the idea, and in fact, I personally think it is a brilliant idea, it might take some time to fly because these rituals come with a package of ancestral rules.

My recommendation is rather to tap into open traditional cultural festivals such as cultural dance festivals. The local government can partner with the private sector and the community

Cultural clubs will need to be established and if I may use the football model, compete from ward level and winners from each ward will then compete to get to an overall winner. Monetary awards and maybe trophies can be given to a winner. The role of traditional leaders will then be to promote this as a cultural tourism attraction. The pouring in of tourists will result in the sustenance of the project as they will be charged an entrance fee, emergence of more businesses in the form of local accommodation, local produce, and arts such as beadwork for traditional regalia. Even tourists may want to buy this artwork to take back home as souvenirs

\section{References}

Cultural Tourism in South Africa: http://www.calabashtours.co.za/ethics/resources/70.html

Devos, A, Strydom, H. Fouche, C. B. and Delport,C, S, L.(2011). Research at Grass Roots: For the social sciences and human service professions. $4^{\text {th }}$ ed. Cape Town. Van Schaik Publishers

Invanovic, M.(2008). Cultural Tourism. Juta and Company Ltd, South Africa

Ministerial conference on Cultural Tourism and poverty alleviation (2004). Hue, Vitnam

Mpungose, N. (2010). Seminar on Heritage and Cultural Tourism as a means of economic development for rural areas.

Smith,K. M. (2009).Issues in Cultural Tourism studies. Publisher Routledge: London \& New York

South African Government News Agency. http://www.sanews.gov.za/south-africa/traditional-leadership-vital-rural-development. 
Accesssed on24/06/2013

South Coast Tourism. http://www.southcoasttourism.co.za/en/aboutsouthcoast.aspx. Accessed on 24/06/2013

Timothy, D. J. (2011). Cultural Heritage and Tourism: An introduction. Channel View Publications: Bristol. Buffalo. Toronto 